\title{
The Impact of Market Orientation on Customer Satisfaction of Private Schools in Jordan
}

\author{
Shadi M. Altarifi ${ }^{1}$, Ibrahim S. Aqel ${ }^{1} \&$ Khaled A. Al Tarawneh ${ }^{1}$ \\ ${ }^{1}$ Marketing Department, Administrative and Financial Science Faculty, Petra University, Amman, Jordan \\ Correspondence: Shadi M. Altarifi, Marketing Department, Administrative and Financial Science Faculty, Petra \\ University, Amman, Jordan. E-mail: Saltarifi@uop.edu.jo
}

Received: July 7, 2016

Accepted: July 27, 2016

Online Published: August 10, 2016

doi:10.5539/ijbm.v11n9p117

URL: http://dx.doi.org/10.5539/ijbm.v11n9p117

\begin{abstract}
This study aims at identifying the impact of market orientation on customer satisfaction in private schools in Jordan. The population of the study consists of managers of different levels in private schools in Amman. Out of the questionnaires distributed, 158 usable questionnaires were returned with a response rate of $79 \%$. Market orientation was measured based on Markotz model. The findings supported the significant influence of market orientation on customer satisfaction. Hence, practical implications for schools' managers were provided in terms of assessing and monitoring market orientation periodically, to be able to identify where improvements are needed, and to identify which dimensions of market orientation should be considered, especially on competitor orientation.
\end{abstract}

Keywords: market orientation, customers' satisfaction, private schools, Amman, Jordan

\section{Introduction}

In the last few years, Interest in the education Sector has been significantly increased, especially in the Arab world, due to its great impact in the economical progress and the social aspect. Therefore, activities in all aspects: education, financial, banking, tourism, Telecom and health have been developed to support the national economy. This variation in such activities has participated in increasing the demand on the education services, which resulted in quality and quantity development in presenting these services to elevate with the preferred requirements for customers. The previous types of development have participated in increasing the role of marketing. Customers' choices have become the focus of interest for many organizations in order to dominance the competitors. The importance of the customers' prospects and interests made the way through into a marketing concept so as to become a widely acceptable key job in organizations. Hence, the marketing concept has been restructured and the marketing job has become one of the crucial jobs in any organization, as their main objective is the customers' satisfaction. In addition, the literature has emphasized the significance of the marketing concept as the base of the marketing system, as well as a philosophy added to the organizational structure. Market orientation reflects a special vision of the organization, its products and customers. The market orientation devotes itself to provide the organization with the steps required to develop its own philosophy, taking into consideration the time factor, which has become a considerable variable in the customer's preferred list. The fast technological progress and raised competition have created the obligatory to develop a mechanism through which organizations can enhance and analyze marketing data, and work accordingly in developing a set of activities to monitor, analyze, and comply with the rapid market movements; i.e. market orientation, in terms of marketing literature.

Managers' imperative need to be so close to their customers, has motivated them to adapt the marketing concept, which has made the academic researchers in the marketing field to provide guidance in form of practical steps that can be adapted by the managers in order to implement such concept in their organizations. But, despite developing behavior standards to market orientation, academic researchers are still unable to provide full and practical assistance to the managers to allow them to develop in that respect. On the other hand, as a result of the competitive environment, production markets have become customers markets, and the supplier has become the base of competition between the organizations. As customers' expectations regarding a product or a service affect their satisfaction, organizations can-based on that knowledge-work on improving the level of service they present, which would certainly increase their number of customers. The tri-relation between market orientation 
and customers' satisfaction performs a complex triangle. The importance of this study was brought to attention the influence of market orientation on customers' satisfaction of private schools in Jordan. On one hand; and being related to a sensitive sector that directly affects the national economy, on the other hand. Also, the importance of this study is tightly bounded to enriching the marketing knowledge of the concerned parties, by emphasizing the impact of market orientation on customers' satisfaction. It can be said, whatever results and recommendations arose based on this study may be used as an affirmative and comprehensive tool. So the study came with an objective to investigate the impact of market orientation using customer orientation, competitor orientation and inter-functional coordination on customers' satisfaction of private schools in Jordan.

\section{Theoretical Framework and Hypotheses Development}

\subsection{Market Orientation}

Market orientation refers to processes and activities intended to satisfy customers (Uncles, 1988). According to marketing researchers, market orientation is the basis of marketing decisions (Shapiro, 1988); organizational culture or climate, which inspires personnel to be more effective in their behavior (Deshpande, 1989), the actions and marketing strategies of the organization (Kohli \& Jaworski, 1990), superior skills (Day, 1994), crucial success factor in companies (Hunt \& Morgan, 1995), a feature of organizational culture (Narvar \& Slater, 1994), a set of behaviors and processes (Gatignon \& Xuereb, 1997). However, Slater and Narver (1990) regarded market orientation as essential element of business culture required for creating necessary behaviors, providing customers with a superior value and enhancing business performance. Consequently, market orientation is multidimensional construct consists of competitor orientation, customer orientation and inter-functional coordination.

In the literature, two perspectives of market orientation were suggested (Lafferty \& Hult, 2001). The first perspective (the behavioral view) was studied and measured by by Kohli and Jaworski (1990) using the Markor scale in terms of intelligence generation and dissemination as well as responsiveness. The second perspective for market orientation (the cultural view) was studied and measured by Narver and Slater (1990) using a whole different measurement scale called Mktor scale in terms of competitor orientation, customer orientation and inter-functional coordination. The scale aims at studying the three elements of cultural perspective of market orientation, i.e., customer, competitor and inter-functional coordination by a three categorized groups consist of 15 questions. The first one is about customer orientation (6 items), while the second one is about competitor orientation (4 items), and the last group of questions consists of 5 items which measures the inter-functional coordination.

\subsection{Customer Satisfaction}

Solomon et al. (2006) defined customer satisfaction in terms of the overall feelings of an individual that he or she about a product after it has purchased. For organizations to satisfy customer, organizations have to deliver the right products in order to play down the differences between customers' requirements and expectations (McKenna, 1991). In relation to customer satisfaction measurement, Day (1977) suggested studying the individual parts of service to learn customer real feelings and then add them together to get the overall evaluation. Recent researchers found that when customer expectation equals service quality, they are satisfied, and vice versa. Five factors were suggested by Huang (1998) to assess customer satisfaction: product, staff, service, closeness to expectation and overall performance of products. Customer satisfaction is the reflection of the customers' attitude. It is not a quantified and objective measure.

\subsection{Market Orientation and Customer Satisfaction}

According to progress from talking about the impact of market orientation on customer satisfaction and through previous studies that the research in that effect, have been linked one way or another between the interest and orientation of organizations to their services provided to customers and its quality related to the satisfaction of these customer from those organizations (Harris \& Ogbonna, 2001), has had to organizations and as a result of the intensity of competitive intensify study their customers and their needs in order to gain access to their expectations and meet the image that was painted from them to those organizations, and therefore we can say that the connection point is between the concept of market orientation and satisfaction with customers. Based on the above literature reviewed, the research hypothesis is:

H1. Market orientation directly influences customer satisfaction of private schools in Jordan

More specifically:

H1a. Competitor orientation directly influences customer satisfaction of private schools in Jordan 
H1b. Customer orientation directly influences customer satisfaction of private schools in Jordan

H1c. Inter-functional coordination directly influences customer satisfaction of private schools in Jordan.

\section{Research Framework}

The conceptual framework of this study can be seen in Figure 1. It presents the presumed relationship between the dimensions of market orientation and customer satisfaction.

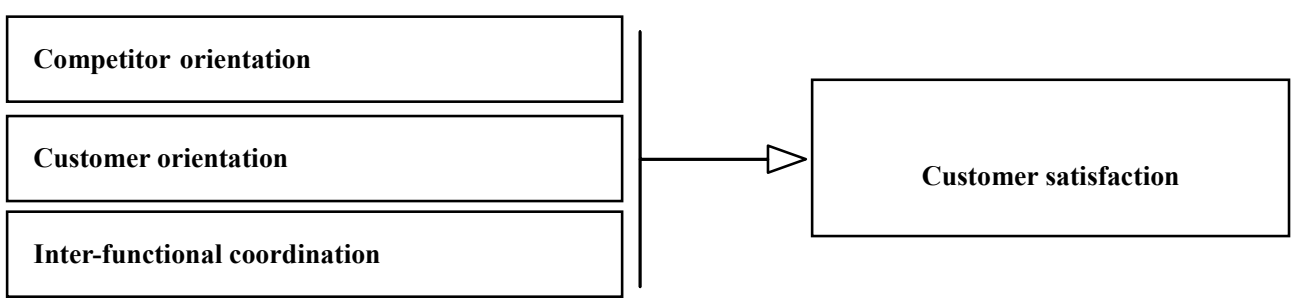

Figure 1. The research framework

\section{Methodology}

The methodology section of the current research depicts the sample of the study, the measurements, the statistical analysis tools employed to test the relationship between study constructs.

\subsection{Sample}

The study population consists of managers of different levels in national and international private schools in Amman in order to measure market orientation variable who appears to be 256 managers over all the schools. This study was completed from Aug. to Sep. in 2014. A random sample was taken with (7\%) from the population (Krejcie \& Morgan, 1970). The sample of the study comprises 200 subjects. There were 23 (14.6 per cent) were below 25 years old, (49.4 percent) were between 25 and 35 years old, another (27.8 percent) were between 35 and 45 years old, and ( 8.2 per cent) were 45 years old and more. Finally, regarding, education, (81.6 per cent) were bachelor degree, and (18.4 percent) were higher education degree, the summary of the sample characteristics shown in Table 1.

Table 1. Sample characteristics

\begin{tabular}{llll}
\hline Variable & & $\mathbf{N}$ & $\mathbf{\%}$ \\
\hline \multirow{4}{*}{ Age } & Less than 25 & 23 & 14.6 \\
& 25- less than 35 & 78 & 49.4 \\
& 35- less than 45 & 44 & 27.8 \\
\multirow{2}{*}{ Education } & 45 and more & 13 & 8.2 \\
\hline & Bach & 129 & 81.6 \\
& Higher education & 29 & 18.4 \\
\hline
\end{tabular}

\subsection{Measures}

Market orientation was measured based upon Markotz model (Narver \& Slater, 1990). They developed a multi-item scale to assess market orientation construct (Narver \& Slater, 1990), which composed of competitor orientation, customer orientation and inter-functional coordination. The final version of the scale after modifications consisted of 15 -item scale designed on a five-point Likert scale ranging from "strongly disagree" to "strongly agree". Examples of items used to evaluate customer orientation include: "our business objectives are driven by customer satisfaction. Competitor orientation, which refers to understanding of strengths, weaknesses, capabilities, and strategies of competitors (Deshpande et al., 1993). Examples of items include "our organization collects information concerning competitors' activities. On the other hand, Inter-functional coordination presents the utilization of resources to create superior value to customers. (Narver \& Slater, 1990). Examples of items include: "all of our business functions and departments are responsive to each other's needs and requests".

Consumer satisfaction. derives from the process of comparison (Oliver, 1993). It was the comparison customers 
make between their expectations before they receive the service and the perception they form after they receive the service. It was a comprehensive judgment customers make on the quality of service. It was, a subjective judgment produced in customers' mind after they receive the service. Customer satisfaction dimension which is composed of: (corporate image, attendants, convenience, promotion, and facility) and this model was adopted from prior researches (Huang, 1998; Kuo, 1999; Fan, 1999; Wu, 2003; Chou, 2003). Minor modifications were, however, made to some items in the original scale to adjust for semantic meanings resulting in a 10-item scale. Each item related to Customer satisfaction context was rated on a five-point Likert scale ranging from "strongly disagree" to "strongly agree". Examples of items include:

\section{1) Customers never regretted dealing with this School}

\section{2) Reliability of research instrument and measurement scales}

After the survey had been completed the reliability of the scales was used to examine the internal consistency of degree of market orientation scale between various factors influencing customer satisfaction for validity by computing their coefficient alpha (Cronbach alpha). After analyzing the total scale and respective, a higher a value indicated a higher internal consistency within the questionnaire as a whole (Wang, 2005). According to Sekaran (2000) mention, it is a low and acceptable standard if the Cronbach Alpha is 0.6. All scales were found to exceed a minimum threshold of 0.6. Convergent validity is also suggested when the individual variable scores are combined into a single scale to give a Cronbach alpha of 0.831 .

Factors of market orientation include competitor orientation, customer orientation and inter-functional coordination. Cronbach's a were $.82, .76, .81$, respectively. Customer satisfaction. Cronbach alpha was .85 . It has shown that the reliability between market orientation, and Customer satisfaction was good and it was in accordance with the internal factors. The actual results of the scale reliability analysis are reported in Tables 2 and 3.

Table 2 . Scale reliability of the market orientation variables

\begin{tabular}{llll}
\hline Construct and item & $\begin{array}{l}\text { Item to total } \\
\text { correlation }\end{array}$ & $\begin{array}{l}\text { Scale alpha if } \\
\text { item deleted }\end{array}$ & Reliability \\
\hline Competitor & & & 0.82 \\
oO1 & 0.33 & 0.38 & \\
CO2 & 0.30 & 0.53 & \\
CO3 & 0.31 & 0.50 & \\
CO4 & 0.29 & 0.48 & \\
CO5 & 0.41 & 0.52 & \\
\hline Customer $\quad$ orientation ( CUO) & & & \\
\hline CUO1 & 0.55 & 0.53 & \\
CUO2 & 0.49 & 0.60 & \\
CUO3 & 0.45 & 0.68 & \\
CUO4 & 0.44 & 0.64 & \\
CUO5 & 0.42 & 0.62 & \\
\hline Inter -functional coordination ( IFC) & & & \\
\hline IFC1 & & \\
IFC2 & 0.32 & 0.53 \\
IFC3 & 0.49 & 0.71 \\
IFC4 & 0.50 & 0.69 & \\
IFC5 & 0.46 & 0.62 & \\
\hline
\end{tabular}


Table 3. Scale reliability of the customer satisfaction

\begin{tabular}{|c|c|c|c|}
\hline Construct and item & Item to total correlation & $\begin{array}{l}\text { Scale alpha if } \\
\text { item deleted }\end{array}$ & Reliability \\
\hline Customer satisfaction (CS) & & & 0.85 \\
\hline CS1 & 0.30 & 0.46 & \\
\hline CS2 & 0.29 & 0.44 & \\
\hline CS3 & 0.40 & 0.53 & \\
\hline CS4 & 0.52 & 0.60 & \\
\hline CS5 & 0.42 & 0.43 & \\
\hline CS6 & 0.48 & 0.39 & \\
\hline CS7 & 0.47 & 0.41 & \\
\hline CS 8 & 0.52 & 0.57 & \\
\hline CS9 & 0.50 & 0.61 & \\
\hline $\mathrm{CS} 10$ & 0.43 & 0.59 & \\
\hline
\end{tabular}

\subsection{Correlation Analysis}

The correlation matrix was calculated to identify bivariate links among the variables of the study. The results of these correlations can be viewed in Table 4 .

Table 4. Summary of correlations

\begin{tabular}{|c|c|c|c|c|c|c|}
\hline Variables & Mean & S.D & CS & $\mathrm{CO}$ & CUO & IFC \\
\hline CS & 3.58 & 1.19 & 1 & $0.15 * *$ & $0.24 * *$ & $0.36^{* *}$ \\
\hline $\mathrm{CO}$ & 3.37 & 1.06 & & 1 & $0.43^{* *}$ & $0.51 * *$ \\
\hline CUO & 3.16 & 0.95 & & & 1 & $0.32 * *$ \\
\hline IFC & 3.10 & 1.08 & & & & 1 \\
\hline
\end{tabular}

** Correlation is significant at the 0.01 level (2-tailed).

The correlation matrix illustrated in Table 4 highlighted that the correlation coefficients were ranging from $(0.15)$ to $(0.51)$. According to the table, dimensions of market orientation (customer orientation, inter-functional coordination, and competitor orientation) were positively correlated to customer satisfaction $(\mathrm{r}=0.36,0.24$, and $0.15, \mathrm{p}<0.01$ respectively). The highest value of correlation coefficient between independent variables was (0.51), which indicated that the model of the study is free of multicollinearity (Hair et al., 1998).

\subsubsection{Descriptive Statistics Analysis}

The statistical description of market orientation dimensions and customer, shown in table (4), indicated that competitor orientation is most prevalent dimension of market orientation $(\mathrm{M}=3.37, \mathrm{SD}=1.06)$, then customer orientation $(\mathrm{M}=3.16, \mathrm{SD}=0.95)$ followed by inter-functional coordination $(\mathrm{M}=3.10, \mathrm{SD}=1.08)$.

\subsubsection{Multiple Regression Analysis}

The influence of market orientation on customers' satisfaction was analyzed using multiple regression analysis. According Hair et al. (1998), it is a constructive statistical technique used to examine the relationship between a single response and several predictors. Particularly, simultaneous regression analysis was conducted, so all study constructs were entered together. Regression results are shown in Table 6 . The tolerance values were more than 0.10 and the values of variance inflation factor (VIF) were less than ten. Hence, the model is free of any serious multicollinearity problem (Hair et al., 1998). On the basis of the analysis, one can concluded that the model of multiple regression used in this study met the assumptions required to ensure validity of its significance test (Ooi et al., 2007b). Accordingly, there was a significant link between market orientation dimensions and customer satisfaction. 
Table 5. Regression summary of market orientation to customer satisfaction $(\mathrm{N}=158)$

\begin{tabular}{|c|c|c|c|c|c|c|c|c|}
\hline \multicolumn{2}{|c|}{ Model } & \multicolumn{2}{|c|}{$\begin{array}{l}\text { Unstandardized } \\
\text { Coefficients }\end{array}$} & \multirow{2}{*}{$\begin{array}{l}\text { Standardized } \\
\text { Coefficients } \\
\text { B }\end{array}$} & \multirow[t]{2}{*}{$\mathbf{T}$} & \multirow[t]{2}{*}{ Sig. } & \multicolumn{2}{|c|}{$\begin{array}{l}\text { Collinearity } \\
\text { Statistics }\end{array}$} \\
\hline & & B & Std. error & & & & Tolerance & VIF \\
\hline \multirow[t]{4}{*}{1} & Constant & 1.158 & 0.156 & & 7.437 & 0.000 & & \\
\hline & competitor orientation & 0.268 & 0.035 & 0.345 & 7.630 & 0.000 & 0.657 & $\begin{array}{l}1.52 \\
2\end{array}$ \\
\hline & customer orientation & 0.116 & 0.036 & 0.135 & 3.246 & 0.001 & 0.775 & $\begin{array}{l}1.29 \\
0\end{array}$ \\
\hline & $\begin{array}{l}\text { inter-functional } \\
\text { coordination }\end{array}$ & 0.125 & 0.039 & 0.144 & 3.178 & 0.002 & 0.656 & $\begin{array}{l}1.52 \\
5\end{array}$ \\
\hline
\end{tabular}

Notes. R 2 = 0.293; Adj. R 2 = 0.288; Sig. F = 0.000; F-value = 71.666; dependent variable, customer satisfaction. $\mathrm{p}<0.01$.

The correlation of market orientation and customer satisfaction was positive $(r=0.541, \mathrm{p}<.01)$. Table 6 shows the regression analysis for market orientation and customer satisfaction. About $29.3 \%$ of the variance in customer satisfaction can be explained by the three dimensions of market orientation $\left(R^{2}=0.293\right)$. The proposed model was adequate as the F-statistic $=71.666$ were significant $(\mathrm{p}<0.01)$. This indicates that the overall model was reasonable fit and there was a significant correlation between market orientation dimensions and customer satisfaction. The individual model variables revealed that competitor orientation, $(\beta=0.268, \mathrm{t}=7.630, \mathrm{p}<0.01)$, customer orientation $(\beta=0.116, t=3.246, p<0.01)$, and inter-functional coordination $(\beta=0.125, \mathrm{t}=3.178, \mathrm{p}>$ 0.01 ) were revealed to have a positive relationship with customer satisfaction. So that customer orientation, competitor orientation as well as inter-functional coordination have high contributions in the research model.

\section{Discussion}

The findings of the presents study confirmed the positive tendency towards market orientation applications. According to the results, the cultural aspects were the most construct discussed in relation to market orientation. Also, it is consistent with the conclusion that: researchers emphasized that dealing with market orientation as a group of behaviors, activities and practices rather than as a feature of organizational culture may benefit the organization though both viewpoints are precious (Hurley \& Hult, 1998). After examining the results, it is clear that the highest degree of implementation was for competitor orientation with a mean of 3.37 , because creating value and keeping the satisfied customers are the major goals for market oriented firms (Day, 1994), followed by customer orientation with a mean of 3.16, and the lowest degree of implementation was for inter-functional coordination. Furthermore, the results showed a high level of customer satisfaction construct, as its mean was 3.58 with a standard deviation of 1.19 . The researcher proposed that the surrounding affects positively and reinforces of private schools in Amman to maximize the level of implementation of market orientation leading to customers' satisfaction. The results showed the presence of a statistical significant positive relationship between applying market orientation concept and customer satisfaction This study concluded that competitor orientation has the highest degree of impact on customer satisfaction (Beta=0.345), followed by inter- functional coordination (Beta $=0.144)$, Customer orientation has a beta of $(B e t a=0.135)$. Marketing researchers have concentrated their efforts upon two orientations which are customer orientation and competitor orientation (Gatignon \& Xuereb, 1997; Menguc \& Auh, 2005; Narver \& Slater, 1990).

\section{Practical Implications and Future Research}

Various implications were revealed for managers of private schools in Amman, particularly in relation to the influence of market orientation on customers' satisfaction. The findings suggested that market orientation dimensions play an important role in fostering customers' satisfaction. Hence, a periodical assessment of market orientation should be considered in order to identify the required improvements. Competitor orientation was the most dimension affected customer' satisfaction, therefore, managers of private schools is required to track their competitors in an efficient and effective manner using different tools such as formal and informal ones such as marketing intelligence. Additionally, value-driven capabilities should be adopted by managers in order to provide their customers with a superior value. Managers also can use participation-intended techniques, i.e., websites and focus groups to explore their customers' needs and wants. Finally, structure-based modifications such as internal and external communications as well information sharing can be implemented to facilitate coordination tasks between schools and their customers. 


\section{Limitations and Future Research}

Numerous limitations were encountered by the current study. The first one is related to the nature of the industry studied, which limited to private schools. Therefore, cautious generalization of the findings should be considered. The small size of the sample is the second limitation. Thirdly, the results of the presents study should not be generalized on other countries since the study was conducted in one country. In a word, further research is required to bypass such limitations by conducting similar studies in different industries, in different countries with more components and models.

\section{References}

Baker, D. A., \& Crompton, J. L. (2000). Quality Satisfaction and Behavioral Intentions. Annals of Tourism Research, 27(3), 785-804. http://dx.doi.org/10.1016/S0160-7383(99)00108-5

Barksdale, H. C., \& Darden, B. (1971). Marketers' attitude toward the marketing concept. Journal of Marketing, 35, 29-36. http://dx.doi.org/10.2307/1250454

Barsky, J., \& Nash, L. (2002). Evoking emotion: Affective keys to hotel loyalty. Cornell Hotel and Restaurant Administration Quarterly, 43(2), 39-46. http://dx.doi.org/10.1016/S0010-8804(02)80007-6

Chen, C. T. (2004). A Study on Customer Satisfaction and Behavioral Intentions of the Service Quality for Fixed Network Communication-An Example of Chunghwa Telecom Company Kaohsiung. Master Dissertation, Yi-Shou University, Kaohsiung, Taiwan.

Chou, F. C. (2003). The Relationship Research of Customer Satisfaction, Convenience, Word of Mouth, and Repurchase in Taipei Health Club. Unpublished Master Dissertation, Chinese Culture University, Taipei, Taiwan.

Churchhill, G. A., \& Surprenant, C. (1982). An investigation into the determinants of customer satisfaction. Journal of Marketing Research, 19, 491-504. http://dx.doi.org/10.2307/3151722

Czepiel, J. A., Larry, J. R., \& Adebayo, A. (1974). Perspectives on Consumer Satisfaction. AM A Conference Proceeding, 119-123.

Day, G. S. (1994). The capabilities of market driven organizations. Journal of Marketing, 58, 37-52. http://dx.doi.org/10.2307/1251915

Day, R. L. (1997). Extending the Concept of Consumer Satisfaction. Advances in Consumer Research, 4, 149-154.

Deshpande, R., \& Farley, J. (1988). Measuring market orientation: Generalization and synthesis. Journal of Market Focused Management, 2(3), 213-32. http://dx.doi.org/10.1023/A:1009719615327

Deshpande, R., \& Webster, F. E. (1989). Organizational culture and marketing: Defining the research agenda. Journal of Marketing, 53, 3-15. http://dx.doi.org/10.2307/1251521

Deshpande, R., Farley, J., \& Webster, F. (1993). Corporate culture, customer orientation and innovativeness in Japanese firms: A quadrad analysis. Journal of Marketing, 57, 23-37. http://dx.doi.org/10.2307/1252055

Engel, J. F., \& Blackwell, R. D. (1982). Consumer Behavior. New York: Holt, Rinehart and Winston.

Fan, C. M. (1999). A Study of Consumer Behavior of the Sport and Health Club Members in Taipei Metorpolis. Master Dissertation, National Taipei University of Physical Education, Taipei, Taiwan

Fornell, C. (1992). A national customer service barometer: The Swedish experience. Journal of Marketing, 56(1), 6-21. http://dx.doi.org/10.2307/1252129

Fornell, C., Johnson, M. D., Anderson, E. W., Cha, J., \& Bryant, B. E. (1996). The American customer satisfaction index: Nature, purpose, and findings. Journal of Marketing, 60(4), 7-18. http://dx.doi.org/10.2307/1251898

Gatignon, H., \& Xuereb, J. M. (1997). Strategic orientation of the firm and new product performance. Journal of Marketing Research, 34(1), 77-90. http://dx.doi.org/10.2307/3152066

Hair, J. F. Jr., Anderson, R. E., Tatham, R. L., \& Black, W. C. (1998). Multivariate Data Analysis (5th ed.). Prentice-Hall International, Upper Saddle River, NJ.

Harris, L., \& Ogbonna, E. (2001). Strategic human resource management, market orientation, and organizational $\begin{array}{lllll}\text { performance. Journal of } & \text { Business }\end{array}$ http://dx.doi.org/10.1016/S0148-2963(99)00057-0 
Houston, F. (1986). The marketing concept: What it is and what it is not. Journal of Marketing, 50(2), 81-7. http://dx.doi.org/10.2307/1251602

Huang, M. C. (1998). An Empirical Study on the Model of Relationship Value-Loyalty for the Banking Industry. Master Dissertation, National YunLin University of Science \& Technology, Yunlin, Taiwan.

Hunt, K. H. (1977). Customers Satisfaction/ Dissatisfaction-Overview and Future Directions, Conceptualization and Measurement of Customer. Cambridge, MA: Marketing Science Institute.

Hunt, S. D., \& Morgan R. M. (1995). The comparative advantage theory of competition. Journal of Marketing, 59(2), 1-16. http://dx.doi.org/10.2307/1252069

Hurley, R. F., \& Hult, G. T. M. (1998). Innovation, market orientation and organizational learning: An integration and empirical examination. Journal of Marketing, 62(3), 42-54. http://dx.doi.org/10.2307/1251742

Jaworski, B., \& Kohli, A. K. (1993). Market orientation: Review, refinement, and roadmap. Journal of Market Focused Management, 1(2), 35-119.

Johnson, M. D., Anderson, E. W., \& Fornell, C. (1995). Rational and adaptive performance expectations in a customer satisfaction framework. Journal of Consumer Research, 21, 695-707. http://dx.doi.org/10.1086/209428

Kohli, A., \& Jaworski, B. J. (1993). Market orientation: The construct, research propositions, and managerial implications. Journal of Marketing, 54, 1-18. http://dx.doi.org/10.2307/1251866

Kotler, P. (1977). From sales obsession to marketing effectiveness. Harvard Business Review, 55(6), 67-75.

Kotler, P., \& Gary, A. (1999). Principles of Marketing. New Jersey: Prentice-Hall Inc.

Krejcie, R. V., \& Morgan, D. W. (1970). Determining sample size for research activities. Educational and Psychological Measurement, 30, 607-610.

Kumar, K., Subramanian, R., \& Youger, C. (1998). Examining the market orientation performance relationship, a $\begin{array}{llll}\text { context-specific study. Journal of } & \text { Management, }\end{array}$ http://dx.doi.org/10.1177/014920639802400204

Kuo T. P. (1999). The Study of Customer Satisfaction Measurement Model of Service Industry. Unpublished Master Dissertation, National Sun Yat-Sen University, Kaohsiung, Taiwan.

Lado, N. R., Maydeu-Olivares, A., \& Martinez, M. A. (1998). El Nivel de la Orientacio'n al Mercado en las Empresas Aseguradoras en España y en el resto de Europa. Revista Espan ola de Investigaciones en Marketing-Esic, 2, 99-113.

Lafferty, B. A., \& Hult, G. T. M. (2001). A synthesis of contemporary market orientation perspectives. European Journal of Marketing, 35(1/2), 92-105. http://dx.doi.org/10.1108/03090560110363364

Levitt, T. (1960). Marketing Myopia. Harvard Business Review, 45-56.

Liu, Y. C., Liu, H. H., Liu, Y. P., \& Liao, W. L. (2001). Learning Swimming from Playing. Taiwan, Kaohsiung: Li-Wen Publication.

McCarthy, E. J., \& Perreault, W. D. (1984). Basic Marketing (8th ed.). Irwin, Homewood, IL.

McKenna, R. (1991). Relationship marketing; Successful strategies for the age of the customer. Reading, Addison-Wesley.

McLeish, B. J. (1995). Marketing for Nonprofit Organizations. New York: John Wiley \& Sons.

McNamara, C. (1972). The present status of the marketing concept. Journal of Marketing, 36(1), 50-57. http://dx.doi.org/10.2307/1250868

Menguc, B., \& Auh, S. (2005). A test of strategic orientation formation versus strategic orientation implementation: The influence of TMT functional diversity and inter-functional coordination. Journal of Marketing Theory and Practice, 13(2), 4-19. http://dx.doi.org/10.1080/10696679.2005.11658540

Narvar, J. C., \& Slater, S. F. (1994). Does competitive environment moderate the market orientation performance relationship? Journal of Marketing, 58, 46-55. http://dx.doi.org/10.2307/1252250

Narver, J. C., \& Slater, S. F. (1990). The effect of a market orientation on business profitability. Journal of Marketing, 54(4), 20-35. http://dx.doi.org/10.2307/1251757

Oliver, R. L. (1981). Measurement and evaluation of satisfaction processes in retail settings. Journal of Retailing, 
57(1), 515-529.

Oliver, R. L. (1993). Cognitive Affective and Attribute Based of the Satisfaction Response. Journal of Consumer Research, 20, 418-430. http://dx.doi.org/10.1086/209358

Oliver, R. L. (1997). Satisfaction: A Behavioral Perspective on the Consumer. New York: McGraw Hill.

Oliver, R. L. (1997). Varieties of value in the consumption satisfaction response. Advances in Consumer Research, 23(7), 247-254.

Olsen, L. L., \& Johnson, M. D. (2003). Service equity, satisfaction and loyalty: From transaction specific to cumulative evaluations. Journal of Service Research, 5(3), 184-195. http://dx.doi.org/10.1177/1094670502238914

Ooi, K. B., Bakar, N. A., Arumugam, V., Vellapan, L., and Loke, K. Y. (2007). Does TQM influence employees' job satisfaction? An empirical case analysis. International Journal of Quality \& Reliability Management, 24(1), 62-77. http://dx.doi.org/10.1108/02656710710720330

Ostrom, A., \& Iacobuci, D. (1995). Consumer Trade-Off \& the Evaluation of Services. Journal of Marketing, 59, 17-28. http://dx.doi.org/10.2307/1252011

Rosen, D. E., \& Suprenant, C. (1998). Evaluating relationships: Are satisfaction and quality enough? International Journal of Service Industry Management, 9(2), 103-125. http://dx.doi.org/10.1108/09564239810210451

Shapiro, B. P. (1988). What the hell is market-oriented? Harvard Business Review, 66, 119-25.

Solomon, M., Bamossy, G., Askegaard, S., \& Hogg, M. K. (2006). Consumer Behaviour-A European Perspective. F Harlow: Inancial Times Prentice Hall.

Uncles, M. (2000). Market orientation. Australian Journal of Management, 25(2), 1-4. http://dx.doi.org/10.1177/031289620002500201

Webster, F. E. (1988). The rediscovery of the marketing concept. Business Horizons, 31(3), 29-39. http://dx.doi.org/10.1016/0007-6813(88)90006-7

Wu, C. C. (2003). The Study on Service Quality and Customer Satisfaction of The Leisure Club-As an Example of the Taipei Yuan Shan Club. Master Dissertation, National Taipei University, Taipei, Taiwan.

Yang, S. U. (2007). An Integrated Model for Organization-Public Relational Outcomes, Organizational Reputation, and Their Antecedents. Journal of Public Relations Research, 19(2), 91-121. http://dx.doi.org/10.1080/10627260701290612

\section{Copyrights}

Copyright for this article is retained by the author(s), with first publication rights granted to the journal.

This is an open-access article distributed under the terms and conditions of the Creative Commons Attribution license (http://creativecommons.org/licenses/by/4.0/). 